\title{
PD-1/PD-L1 inhibitors as a hope for smokers of non-small cell lung cancer patient
}

\author{
Zhuo Yu ${ }^{1}$, Peiqing Zhang ${ }^{1}$, Weikuan $\mathrm{Gu}^{2}$, Xicheng Jiang ${ }^{3}$ \\ ${ }^{1}$ Heilongjiang Academy of Traditional Chinese Medicine, Harbin 150036, China; ${ }^{2}$ Department of Orthopedic Surgery and BME, University of \\ Tennessee Health Science Center, Memphis, TN, USA; ${ }^{3}$ College of Basic Science, Heilongjiang University of Chinese Medicine, Harbin 150040, \\ China \\ Correspondence to: Weikuan Gu. 956 Court Ave, Memphis, TN 38163, USA. Email: wgu@uthsc.edu; Xicheng Jiang. Heping Road 24, Xiangfang \\ District, Harbin 150040, China. Email: jiangxicheng5303@163.com.
}

Submitted Jul 27, 2019. Accepted for publication Nov 29, 2019.

doi: $10.21037 /$ tcr.2019.12.22

View this article at: http://dx.doi.org/10.21037/tcr.2019.12.22

We read with great interest the recent review article by Warren (1) on the adverse health effects and costs associated with smoking after a cancer diagnosis. We noticed Dr. Warren concluded that priority should be placed on interventions that reduce the effect of medication and associated costs caused by continued smoking after a cancer diagnosis. Dr. Warren also pointed out that research is desperately needed to ascertain if the adverse effects of smoking can be overcome with an existing or forthcoming cancer treatment. We wondered whether Dr. Warren noticed the recently reported clinical trials on the effects of drugs of programmed death-1 (PD-1) and programmed death-ligand 1 (PD-L1) inhibitors on non-small cell lung cancer (NSCLC), and whether Dr. Warrant could comment on the potential benefit of PD-1 and PD-L1 drugs to NSCLC patients who are still smoking.

First of all, we all know that smoking is harmful and greatly increases the risk of lung disease as has been confirmed many times over years of study. However, our question seeks to address the effect of smoking on treatment of lung cancer, i.e., how smoking lung cancer patients respond to treatment by variety of drugs. Smoking status has been analyzed in some but not all clinical trials of new drugs. Recent data from several clinical trials have indicated that it may be necessary to compare data on the effects of treatment among subgroups according to smoking status. We believe that future clinical trials should always include such analysis.

Smoking status of patients studied has been reported in the majority of large clinical trials. In the past, most of these results indicated that smoking negatively affects treatment for cancer patients (2). However, the induction of lung cancer and the effects of cancer treatment are not the same. Different drugs have different mechanisms and affect different molecular pathways in different cancers. PD-1/ PD-L1 inhibitors are relatively new types of drugs used in the treatment of cancer. Therefore response to treatment by PD-1/PD-L1 inhibitors should be carefully compared among patients differing in smoking status before any conclusions can be definitively reached.

In particular, two recent clinical trials of a PD-1 inhibitor in cancer patients reported that treatment by PD-1/PD-L1 inhibitors was more effective in smokers than non-smokers $(3,4)$. In both publications the authors provided hazard ratio (HR) values as measured by median overall survival (OS) for patients from two different smoking status groups, the ever (smoker) and the never (smoker). In the report by Mok et al., the authors analyzed the effect of pembrolizumab versus chemotherapy for previously untreated, PD-L1expressing, locally advanced or metastatic NSCLC (3). Pembrolizumab is one of a family of PD-1/PD-L1 inhibitors. The authors reported response to treatment by patients having different smoking histories. In their three sub-group analyses, smokers had lower HR values than that the non-smokers in all of them (Table 1).

Further, an early report by Reck et al. on pembrolizumab versus chemotherapy for PD-L1 positive NSCLC patients, also found that HR values for smokers were lower than those of non-smokers (4). It is unlikely that both studies found spurious results. It is possible that PD-1/PD-L1 inhibitors are drugs that may work better in smokers than 
Table 1 HR of smokers and non-smokers of NSCLC patients treated with PD-1 and PD-L1 drugs

\begin{tabular}{|c|c|c|c|c|c|c|c|}
\hline $\begin{array}{l}\text { Drugs/first } \\
\text { author }\end{array}$ & $\begin{array}{l}\text { Drug } \\
\text { comparison }\end{array}$ & Subgroup analysis & Current/\#patients & $\begin{array}{l}\text { Former/\# } \\
\text { patients }\end{array}$ & $\begin{array}{l}\text { Never/ } \\
\text { \#patients }\end{array}$ & $\begin{array}{l}\text { Overall/ } \\
\text { \#patients }\end{array}$ & Note \\
\hline \multirow[t]{2}{*}{$\begin{array}{l}\text { Pembrolizumab/ } \\
\text { Mok (3) }\end{array}$} & \multirow[t]{2}{*}{$\begin{array}{l}\text { Versus } \\
\text { chemotherapy }\end{array}$} & $\begin{array}{l}\text { Overall survival in } \\
\text { key subgroups }\end{array}$ & $0.71 / 116$ & $0.60 / 352$ & $1.10 / 131$ & $0.69 / 599$ & \multirow[t]{2}{*}{$\begin{array}{l}\text { From its } \\
\text { appendix }\end{array}$} \\
\hline & & $\begin{array}{l}\text { Tumour proportion } \\
\text { Score } \geq 20 \%\end{array}$ & $0.80 / 160$ & $0.65 / 473$ & $1.26 / 185$ & $0.77 / 818$ & \\
\hline $\begin{array}{l}\text { Pembrolizumab/ } \\
\text { Reck (4) }\end{array}$ & $\begin{array}{l}\text { Versus } \\
\text { Chemotherapy }\end{array}$ & $\begin{array}{l}\text { Progression-free } \\
\text { survival }\end{array}$ & $\begin{array}{l}0.68 / 65 \text { (in the } \\
\text { intention-to-treat } \\
\text { population) }\end{array}$ & $0.47 / 216$ & $0.90 / 24$ & $0.50 / 305$ & $\begin{array}{l}\text { All are PD-L1 } \\
\text { expression on } \\
\text { at least } 50 \% \\
\text { of tumor cells }\end{array}$ \\
\hline \multirow{4}{*}{$\begin{array}{l}\text { Durvaluma/ } \\
\text { Sridhar (5) }\end{array}$} & $\begin{array}{l}\text { Study 1108/ } \\
\text { durvalumab } \\
\text { monotherapy }\end{array}$ & HR for PFS & \multicolumn{3}{|c|}{$\begin{array}{l}\text { Ever vs. never: } 0.66 \text { (Cox proportional hazards } \\
\text { model, including PD-L1/LM subgroups) }\end{array}$} & - & - \\
\hline & \multirow{3}{*}{$\begin{array}{l}\text { ATLANTIC/ } \\
\text { Durvalumab } \\
\text { as third-line or } \\
\text { later treatment }\end{array}$} & $\begin{array}{l}\text { Adjusted HR for } \\
\text { OS }\end{array}$ & \multicolumn{3}{|c|}{$\begin{array}{l}\text { Ever vs. never: } 1.67 \text { (by Cox proportional } \\
\text { hazards model) }\end{array}$} & - & - \\
\hline & & HR for OS & \multicolumn{3}{|c|}{$\begin{array}{l}\text { Ever vs. Never: } 1.67 \text { (by Cox proportional } \\
\text { hazards model, including PD-L1/LM subgroups) }\end{array}$} & - & - \\
\hline & & HR for PFS & \multicolumn{3}{|c|}{$\begin{array}{l}\text { Ever vs. never: } 1.08 \text { (by Cox proportional } \\
\text { hazards model, including PD-L1/LM subgroups) }\end{array}$} & - & - \\
\hline
\end{tabular}

HR, hazard ratio; NSCLC, non-small cell lung cancer; PD-1, programmed death-1; PD-L1, programmed death-ligand 1; LM, liver metastases.

non-smokers while for other drugs non-smokers may respond to treatment better than the smokers.

We examined another publication in which the authors obtained controversial results by analyzing data from two clinical studies (Study 1108 and ATLANTIC) (5) that used a different PD-L1 inhibitor, durvalumab. In Study 1108, the HR values of smoker were lower than those of nonsmokers, while the ATLANTIC study found precisely the opposite results. The purpose of Study 1108 was to evaluate the effects of durvalumab monotherapy, whereas the ATLANTIC study evaluated the efficacy of durvalumab as a third-line or later treatment. We reasoned that if the different treatments exerted a differential effect on patients with different treatment histories, this might account for the disparate results between the two studies.

When we compare the reports from Mok et al., Reck et al., Study 1108, and the ATLANTIC study, we see both differences and similarities among the studies (Table 1). The three studies reported by Mok et al., Reck et al., and Study
1108 showed that smokers have better outcomes than nonsmokers when PD-1/PD-L1 inhibitors are used as first line $v s$. treatment with single drugs $v s$. others, $v s$. use as a third-line or later treatment in the ATLANTIC study. Our question now is whether smokers will have better outcomes in response to treatment by various individual PD-1/PD-L1 inhibitors than non-smokers.

While lack of data from detailed analyses of smoking status in many cancer treatment trials renders firm conclusions premature at present, extant data suggest that it is worthwhile to explore the effect of smoking history on response to different drug treatments in future studies, especially those of PD-1/PD-L1 drugs. We look forward to seeing more evidence about response to treatment using PD-1/PD-L1 inhibitors from smokers and non-smokers.

\section{Acknowledgments}

We thank our professional editor, Dr. Amanda Susan 
Clarke, at UTHSC for carefully editing our manuscript. The authors are accountable for all aspects of the work in ensuring that questions related to the accuracy or integrity of any part of the work are appropriately investigated and resolved.

Funding: None.

\section{Footnote}

Provenance and Peer Review: This article is a free submission to the journal. It has undergone external peer review.

Conflicts of Interest: All authors have completed the ICMJE uniform disclosure form (available at http://dx.doi. org/10.21037/tcr.2019.12.22). The authors have no conflicts of interest to declare.

Ethical Statement: The authors are accountable in all respects for ensuring that questions related to the accuracy or integrity of any part of the work are appropriately investigated and resolved.

Open Access Statement: This is an Open Access article distributed in accordance with the Creative Commons Attribution-NonCommercial-NoDerivs 4.0 International License (CC BY-NC-ND 4.0), which permits the noncommercial replication and distribution of the article with the strict proviso that no changes or edits are made and the original work is properly cited (including links to both the formal publication through the relevant DOI and the license). See: https://creativecommons.org/licenses/by-nc-nd/4.0/.

\section{References}

1. Warren GW. Mitigating the adverse health effects and costs associated with smoking after a cancer diagnosis. Transl Lung Cancer Res 2019;8:S59-66.

2. Wang L, Cao Y, Ren M, et al. Sex Differences in Hazard Ratio During Drug Treatment of Non-small-cell Lung Cancer in Major Clinical Trials: A Focused Data Review and Meta-analysis. Clin Ther 2017;39:34-54.

3. Mok TSK, Wu YL, Kudaba I, et al. Pembrolizumab versus chemotherapy for previously untreated, PD-L1expressing, locally advanced or metastatic non-small-cell lung cancer (KEYNOTE-042): A randomized, open-label, controlled, phase 3 trial. Lancet 2019;393:1819-30.

4. Reck M, Rodríguez-Abreu D, Robinson AG, et al. Pembrolizumab versus Chemotherapy for PD-L1Positive Non-Small-Cell Lung Cancer. N Engl J Med 2016;375:1823-33.

5. Sridhar S, Paz-Ares L, Liu H, et al. Prognostic Significance of Liver Metastasis in Durvalumab-treated Lung Cancer Patients. Clin Lung Cancer 2019;20:e601-8.
Cite this article as: $\mathrm{Yu} \mathrm{Z}$, Zhang $\mathrm{P}, \mathrm{Gu}$ W, Jiang X. PD-1/ PD-L1 inhibitors as a hope for smokers of non-small cell lung cancer patient. Transl Cancer Res 2019;8(8):2941-2943. doi: 10.21037/tcr.2019.12.22 